\title{
Dramaturgia e Teatro: Tensão Criativa
}

\section{Elane Lisbôa}

Este texto chama a atenção para as especificidades e interseções do teatro e da dramaturgia.

O título deste artigo pode parecer redundante para muitos, dado que até muito recentemente se compreendia a dramaturgia e a arte do teatro como uma mesma coisa. Justamente, o que se busca com ele é chamar a atenção para as especificidades dessas duas artes, e para os seus pontos de intersecção.

Essencial para a arte teatral, embutida nela como um de seus componentes fundamentais, a dramaturgia no entanto constitui-se em universo específico, que alimenta e movimenta as artes de um modo geral, muito embora tenha sua forma mais tradicional reconhecida na forma do texto dramático.

O que é afinal a dramaturgia, e de que modo ela se interrelaciona com a arte do teatro? E que importância tem isto para o ensino das artes nas escolas de ensino básico e fundamental? Isto é o que nos propomos esclarecer aqui, esperando ainda atender a ansiedades e dialogar com professores de distintas áreas artísticas.

Antes de mais nada, portanto, mais do que apresentar uma visão única do estudo da dramaturgia, dentro da análise do que se convencionou chamar o texto dramático, vamos buscar compreender seus princípios fundamentais, e mostrar como eles se encontram presentes em muitas outras áreas, e não necessariamente restritas ao universo artístico. 
Nos estudos mais tradicionais define-se como princípio essencial da dramaturgia o choque de vontades, o conflito como eixo vetor fundamental, em torno do qual gravitam, gerando situações e movimentos distintos, todos os outros elementos componentes, quais sejam: os personagens, as forças ou actantes, a ação dramática, e o tempo e o espaço como determinantes de um dado desenho dramatúrgico. Dentro disso ainda, a figura de um autor, de visível ou invisível presença, na maioria dos casos detectável pelos elementos que giram em torno das falas dialogais, mas sempre presentes, mesmo que nelas de maneira indireta.

Assim, essencialmente, pode-se dizer que para que um drama se constitua, é imprescindível uma ação, movida por um impulso de vontade, que se confronte a uma barreira determinante da reação de um outro. Estabelece-se a partir daí uma situação de base. Portanto, uma situação dramática será sempre o desenho desse confronto de forças, que tem caráter dinâmico e deve gerar um movimento a caminho de sua própria destruição ou modificação.

Traçar o desenho de uma dramaturgia seria, portanto, reconhecer em cada um de seus instantes, os elementos que comparecem a ele e como se constituem as situações geradas por este momento.

É possível encontrar-se dramaturgia em tudo, pois em todo e qualquer instante, seja de ficção ou de realidade, um conjunto de forças se encontra determinando o "quadro" deste momento. $\mathrm{Na}$ dramaturgia escrita essa confluência se elabora normalmente em torno de uma idéia que se desenvolve gerando novos momentos e situações dramáticas, até chegar-se a algum desenlace da ação dramática fundamental, que move o texto do início ao fim. 
É importante compreender-se que o jogo de forças não é o mesmo que o confronto dos personagens, aquelas sendo representadas por estes, mas sem que os mesmos consigam abarcá-las e compreendê-las na sua extensão total. São as forças em confronto que vão nos dar o desenho do modelo actancial de uma dada situação, jogo dos actantes que encobre e determina o movimento dos personagens.

Para que isto fique mais claro podemos exemplificar com a obra de Shakespeare, Romeu e Julieta. Enquanto os jovens protagonistas movem-se nas situações, forças sociais, de ordem familiar e impulsos atávicos determinam um movimento mais sutil e profundo que vai gerar no final a morte dos dois jovens. O amor e o ódio são modelos de forças que determinam grande parte do movimento dramático identificado na obra.

O modelo actancial, além de determinar o vetor fundamental que caracteriza a evolução da situação dramática, traça o desenho de todos as forças que apóiam ou buscam impedir este movimento.

Esse desenho de um movimento dramático que fazemos numa obra dramatúrgica pode ser transplantado para as outras artes com o mesmo sentido. Numa pintura, por exemplo, há traços fortes e fracos, retos ou curvilíneos, que vão determinar o movimento de nosso olhar, e as tensões de cores e traços no quadro terminam por impornos o sentido da "leitura dramática" que podemos fazer a partir delas. Da mesma maneira, na arte musical os sons, ritmos e melodias constróem uma dramaturgia feita de todos os instantes sonoros, pausas e silêncios que a compreendem.

Podemos dizer inclusive que em qualquer situação cotidiana desenha-se uma dramaturgia, a partir da posição ocupada por cada um dos elementos que a constitui, e que esta pode ter uma maior ou menor dramaticidade, a depender da energia de tensão nela 
concentrada. Momentos de acordo entre os elementos têm menor carga dramática, e momentos de confronto, de encontro de forças opositoras têm maior carga dramática.

\section{Dramaturgia como gênero litterário}

Numa peça dramática, construída a partir das ações dos personagens, o que se faz é colocá-los em situação, isto é, desenhar seu movimento interligandoo ao conjunto de elementos que vão definir e determinar esta mesma situação.

Como gênero literário, a dramaturgia deixa de ser a idéia em si para compreender-se como arte específica, do campo da literatura, contrapondo-se às outras artes literárias como o romance e o conto. E o estudo da dramaturgia, de um modo geral, apóia-se essencialmente na forma literária, nos elementos que compreendem o texto dramático escrito, o que se define como um estudo de gênero afinal.

E o gênero dramático, frente ao gênero épico ou lírico, vai em sua inteireza compreender uma forma específica, constituída de elementos essenciais dentro de seu caráter literário: autor, personagens, rubricas/ didascálias. Forma literária esta marcada essencialmente pelo diálogo, pela ação volitiva presentificada dos personagens, que gera o movimento, que faz com que a situação avance, transforme-se. A dramaturgia é portanto o desenho deste movimento, uma arte essencialmente temporal. Na literatura isto se apresenta dentro de gênero específico, apoiado nos personagens e situações dramáticas.

\section{O teatro, arte do espaço.}

E a arte teatral? É a arte da cena, a arte do espaço físico real, arte visual, sonora, que vai encontrar-se com a arte dramatúrgica no espaço de intersecção da cena, 
onde as duas realidades, a real e a ficcional se encontram. A teatralidade implica na consciência do outro que vê, e o diálogo com este outro - o público constrói-se a partir da dramaturgia, que ganha corpo e realidade cênica.

A confluência de forças em situação se coloca agora a partir de novos elementos, constituidores do espaço e tempo cênicos, duais por sua própria natureza:

$1^{\circ}$ tempo e espaço real. O momento presente da representação - o instante real em que nos encontramos no momento da apresentação, o tempo de duração desta, e o seu espaço real, a realidade física do espaço teatral - sala, palco, platéia.

$2^{\circ}$ tempo e espaço ficcional. A realidade ficcional do contexto dramático - o tempo e lugar das situações vividas pelos personagens.

O encontro destes dois tempos e lugares tem como espaço maior de intersecção a figura do ator, que é a um só "tempo" essas duas realidades, que empresta seu corpo físico, real, para a apresentação de um outro, irreal, ficcional. Ele dá a seu corpo, que é real, um movimento também real, mas através dele nos constrói a imagem deste outro corpo, ficcional, o corpo, a voz, do personagem. A personagem de teatro portanto só existe neste ponto de intersecção, onde a idéia de si mesmo ganha "realidade" e vida através do corpo do ator.

Todos os elementos da cena, inclusive, em sua concretude e realidade presentificada, vão constituir no campo da dramaturgia também um outro tempo/ espaço, inserindo-se no campo da ficção, imbuídos de carga simbólica de múltiplos significados, determinados pela natureza do próprio espetáculo que se apresenta. 
A arte teatral é assim a somatória do desenho dramatúrgico - do encontro dos elementos constituidores das forças que se confrontam no universo ficcional, determinando a dramaticidade da situação - e do desenho cênico que dá novos elementos, amplia e enriquece essa dramaturgia imagens, sons, espaços e energias presentes em cena (no que se inclui o olhar e a "respiração" do público). A situação dramática na cena compõe o instante teatral, e este só existe com e a partir dela. A poesia da cena se faz deste movimento dual.

A dramaticidade do instante cênico constitui-se inclusive do sentido de conjugação de todas as tensões num instante absoluto de tensão, encontrandose na cena todos os fatores e tempos concentrados num tempo/espaço único, de concisão e compressão únicas. Daí o seu caráter de irrealidade, de construto, onde a dramaturgia da cena é a soma de tudo o que se ouve e vê. E o caráter dramático determina no teatral o ponto de máxima tensão, a tensão em progressão permanente.

Tudo isto, que tem um aspecto profundamente teórico, que apresenta-se como abstração, é na verdade um elemento muito importante a ser compreendido para que se possa de fato lidar com a arte teatral, e para que se tenha consciência, a cada instante, do material com o qual se está lidando, quer na construção de um texto dramático escrito, quer na construção da escrita cênica.

E escrever uma dramaturgia é lidar com estes elementos fundamentais: a ação dramática e os elementos que se combinam ou antagonizam-se, gerando o movimento da ação que deve manter-se em crescente dramaticidade e tensão. Na cena teatral, esta dramaturgia, compreendida neste movimento, ganha em realidade e amplia suas forças ao comporse com o conjunto de imagens e sons cênicos. $\mathrm{Na}$ concretude da cena eles apresentam-se 
ressignificados dentro do universo ficcional que constróem. Ea própria tensão, fruto do encontro dessas duas "realidades" - a ficcional e a do presente cênico geram a dramaturgia da cena.

A dramaturgia seria assim, nessa relação com a arte teatral, o caminho traçado que determinou a ordenação de todos os elementos que compõem a situação dramática, estabelecida não mais apenas pelas palavras mas composta ainda de todos os elementos que se encontram presentes no espaço cênico. Elementos concretos, visuais, perceptíveis aos sentidos visuais e auditivos, e elementos abstratos, perceptíveis pelo intelecto e a emoção.

Construir uma dramaturgia é de algum modo compreender a totalidade de um movimento, pesar a importância de cada uma das partes de uma situação, trabalhar com a tensão que se estabelece entre as partes e o todo. No caso do teatro, desenvolver a relação entre os atores - dançarinos e músicos se for o caso - cores, imagens, sons, volumes, ritmos, determinar a disposição no espaço e no tempo, num trabalho apurado de composição.

\section{A construcão teatral}

Construir um espetáculo teatral implica em compreender esses dois universos, o dramatúrgico e o teatral:

- um trabalho de construção dramatúrgica implica na elaboração de momentos de tensão em que forças se confrontam, deste confronto gerando-se o movimento e a evolução da situação,

- e um trabalho de construção cênica, de construção espacial, de reconhecimento do outro que assiste, de colocação de objetos e corpos em cena, em movimento, dando vida a esta dramaturgia. 
Implica ainda na consciência do sentido de concentração e "estetização" desta presentificação do ficcional, da carga poética essencial a ser elaborada no universo dramático e no universo teatral em que ela vai se situar, e que também a determina. Os atores em cena não reproduzem apenas o real, não "copiam" a realidade da ficção ou da vida, mas constróem uma outra realidade, a da cena, onde cada objeto é real mas carregado de carga simbólica. Ele pede para ser visto, para além de sua realidade física de objeto real, essencialmente em sua realidade ficcional, de objeto que significa algo além e fora de si mesmo.

E este sentido que ganha o objeto, e o ator visto aí também como mais um objeto, encontra-se na dramaturgia geral que se constrói na cena teatral, onde cada um dos seus elementos constrói significados e significa-se a partir de todos os outros. E é só na leitura geral e unívoca de tudo o que ocupa o espaço cênico que conseguimos elaborar o tempo / espaço da ficção.

A poesia da cena portanto resulta da carga dramática constituída em sua dramaturgia cênica, em sua teatralidade.

\section{Dramaturgia e teatralidade na sala de aula}

A compreensão desses elementos fundamentais constituidores da arte teatral pode ser de grande auxílio no trabalho escolar. Sabendo-se com que universo se lida pode-se também fazer uso dele no trabalho com os estudantes. E não apenas nas aulas de artes cênicas, pois em todos os momentos do cotidiano vamos encontrar universos a serem analisados dramatúrgica e teatralmente.

As relações de forças implicadas, por exemplo, numa sala de aula já nos permitem desenhar uma certa 
dramaturgia. As relações hierárquicas de ordem familiar do mesmo modo, assim como as relações de vizinhança ou de amizade e coleguismo.

Também é importante tomar consciência do que significa o momento da representação, a situação especial de energia concentrada que se configura no momento da apresentação, o caráter extra-cotidiano desta situação, os novos sentidos que ganham gestos e olhares no instante em que se colocam dentro de um espaço de representação.

Isto permite também ampliar a idéia desse espaço e fazer com que os alunos reconheçam as situações teatrais geradas pela simples colocação de um deles como alguém que se "apresenta" frente ao outro, gerando os dois espaços, o de quem se mostra e o de quem vê. De algum modo dá consciência a eles e ao próprio professor do espaço de teatralidade da sala de aula, onde a energia do professor precisa manter-se num nível extracotidiano, de modo a garantir em permanência a atenção e o interesse dos estudantes. 